Dorota Pielorz

Uniwersytet Jagielloński

\title{
„Festiwal kanadyjskiej pisarki”, czyli o mniej znanych polskich tłumaczeniach Anne of Green Gables Lucy Maud Montgomery
}

\section{Wprowadzenie}

O polskich przekładach powieści Anne of Green Gables Lucy Maud Montgomery mówiono oraz pisano już bardzo wiele (zob. np. Oczko; Szymańska; Oczko, Nastulczyk, Powieśnik; Zborowska-Motylińska) ${ }^{1}$. O ile jednak badacze skupiają się zwykle na kanonicznym przekładzie autorstwa Rozalii Bernsteinowej oraz polemicznych tłumaczeniach Agnieszki Kuc i Pawła Beręsewicza, pozostałe Anie... wydane w latach dziewięćdziesiątych xx oraz na początku XxI wieku postrzegane są często jako zbiór homogeniczny i opisywane w uproszczony, nieraz krzywdzący sposób. Rzecz jasna szczegółowe omówienie ich wszystkich stanowi materiał raczej na obszerną monografię niż kilkunastostronicowy artykuł, warto jednak przynajmniej zarysować problem, zwracając uwagę na kilka ważnych i interesujących aspektów tych tekstów. Dzięki analizie oraz zestawieniu tłumaczeń $\mathrm{z}$ oryginałem można bowiem dowiedzieć się wiele o kulturze docelowej (w tym wypadku polskiej), ale także o rzeczywistości spo-

1 Bodaj najpełniejszy (i - co umożliwia technologia - ciągle uzupełniany przez autorkę) wykaz artykułów dotyczących twórczości Montgomery, także tych poświęconych zagadnieniom translatologicznym, znaleźć można na prowadzonym przez Agnieszkę Maruszewską blogu Pokrewne dusze. Świat Lucy Maud Montgomery w Polsce (Maruszewska, źródło elektroniczne). 
łecznej czy nawet o ówczesnej sytuacji ekonomicznej. Zacząć należy jednak od przypomnienia kilku najważniejszych informacji dotyczących samej powieści, zaprezentowania polskich przekładów oraz pokazania charakterystycznych kierunków ich recepcji.

Anne of Green Gables to powieść opublikowana w 1908 roku. Opowiada historię jedenastoletniej Anne Shirley - osieroconej dziewczynki, która trafia pod opiekę rodzeństwa Marilli i Matthew Cuthbertów. Mimo początkowych problemów ostatecznie udaje się jej znaleźć u nich prawdziwy dom, zostaje też zaakceptowana przez lokalną społeczność, kończy szkołę ze świetnymi wynikami i jako szesnasto-siedemnastoletnia dziewczyna wybiera się do seminarium nauczycielskiego. Na język polski utwór przekładano kilkunastokrotnie, można zatem w tym wypadku mówić o pokaźnych rozmiarów serii translatorskiej (Balcerzan; Legeżyńska; Zarek). Pierwsze tłumaczenie, będące dziełem Rozalii Bernsteinowej (to miano jest jednak najprawdopodobniej tylko pseudonimem - zob. Oczko, Nastulczyk, Powieśnik 270-275), ukazało się już w latach 1911-1912 i do dziś ma status przekładu kanonicznego. Na początku xxI wieku powstały z kolei dwie Anie... otwarcie polemiczne wobec pierwszej polskiej wersji - wspomniane już przekłady Agnieszki Kuc (2003) oraz Pawła Beręsewicza (2012).

W niniejszym artykule refleksja badawcza koncentrować się będzie na tłumaczeniach, które - zarówno pod względem chronologii (zob. tabela 1), jak i zamysłu przekładających oraz realizacji owego zamysłu - znajdują się pomiędzy wyżej wymienionymi. Jednak na przekładach oddziaływanie powieści rzecz jasna się nie kończy. Można wręcz powiedzieć, że jest odwrotnie - to od nich zaczyna się zwykle recepcja obcego utworu w danej kulturze. Biorąc pod uwagę ogrom materiału, całościowe i dogłębne przeanalizowanie polskiej recepcji twórczości Montgomery (a nawet jedynie Anne of Green Gables) wydaje się zadaniem arcytrudnym, niemal niewykonalnym. Niemniej jednak, próbując się go podjąć, można by wykorzystać zaproponowaną przez Martę Skwarę koncepcję serii recepcyjnej (Skwara 2010, 2014). Wówczas oprócz tłumaczeń należałoby zbadać niezliczone ślady funkcjonowania tej powieści (ale również między innymi filmów i seriali opartych na jej motywach) w kulturze polskiej. Można wymienić nawiązujące do niej teksty kultury: powieści, opowiadania, wiersze, przedstawienia teatralne, recenzje, a ponadto poświęcone książkom i osobie pisarki fora internetowe, obchody rocznic wydania oraz towarzyszące im wydarzenia: wystawy, konkursy, spotkania etc. Do tego warto byłoby dodać częste wznawianie wydanych już wcześniej i publikowanie nieznanych utworów Kanadyjki.

Tak ogromne zainteresowanie twórczością Montgomery pozwoliło krytykom mówić o „festiwalu kanadyjskiej pisarki” (Tylicka 1992: 24). Wyrażenie 
to, będące tytułem artykułu Barbary Tylickiej dotyczącego polskiej recepcji twórczości Montgomery, stało się hasłem niezwykle chętnie powtarzanym przez badaczy oraz obserwatorów polskiego rynku książki dla dzieci i młodzieży. Sposób, w jaki fenomen popularności Montgomery wykorzystywali wydawcy, oceniano zwykle negatywnie:

Powodzenie utworów Montgomery na świecie zapewniają głównie czytelnicy, bo ocena i przychylność krytyków bywała różna, co często się zdarza w przypadku literatury popularnej. Wydawcy, jak zawsze czuli na odzewy rynku, stale wznawiają książki kanadyjskiej pisarki. W Polsce po roku 1990 przeżywamy nieustanny festiwal jej twórczości - ukazało się już niemal wszystko co napisała... (Tylicka 2000: 73, podkr. D.P.).

W ostatnich latach wiele wydawnictw swoją kondycję finansową poprawia całymi seriami dawnych powieści dla dziewcząt, nie zwracając na ogół uwagi na ich wartość literacką. Kupują je głównie babcie i co starsze ciocie współczesnych nastolatek, by usłyszeć w nich echo swojej młodości (Skotnicka 1994: 22, podkr. D.P.).

Należy [...] wątpić, czy [L.M. Montgomery - D.P.] byłaby zachwycona wskrzeszaniem przez wydawców jej naiwnych, słabych opowiadań drukowanych w prowincjonalnych pisemkach. No cóż, na Montgomery świetnie się zarabia, trwa więc nadal „festiwal” tej autorki, łącznie z adaptacjami filmowymi i scenicznymi (Horodecka 1994: 21, podkr. D.P.).

Rozsypał się worek z twórczością Lucy Maud Montgomery. [...] cóż, magia Ani z Zielonego Wzgórza działa tak silnie, że czytelnicy chętnie sięgają po kolejne tomiki tej pisarki wydawane non stop przez „Naszą Księgarnię” (a także „Novus Orbis”) (Horodecka 1995: 29, podkr. D.P.).

Badacze akcentują zorientowanie wydawców na kwestie finansowe, „podążanie za zyskiem” bez względu na „wartość literacką” wybieranych do druku tekstów. Należy jednak pamiętać, że niesłabnąca z upływem czasu popularność Ani... to nie tylko marketingowy sukces wydawców, ale i świadectwo pielęgnowania przez wielu dorosłych pamięci o lekturach dzieciństwa oraz dzielenia się nią z potomkami („kupują je głównie babcie i co starsze ciocie współczesnych nastolatek"). W wielu rodzinach egzemplarze powieści przez dziesięciolecia przekazywane były (i nadal są) z pokolenia na pokolenie. Rozpowszechnione, 
chociaż niesłuszne, mniemanie, iż jest to książka „tylko dla dziewcząt”, sprawia, że owa transmisja najczęściej dokonuje się w sposób matrylinearny.

\section{Przekłady w ogniu krytyki}

Nie da się ukryć, że większość ukazujących się na przełomie xx i xxi wieku książek Lucy Maud Montgomery, w tym przekładów Anne of Green Gables, prezentuje dość niski poziom - zarówno jeśli chodzi o szatę graficzną, jak i językowo-stylistyczne ukształtowanie tekstu. Chętnie przywoływany przykład stanowi tłumaczenie Przemysława Piekarskiego, gdzie już od pierwszych stron roi się od wszelkiego rodzaju błędów (stylistycznych, interpunkcyjnych, a nawet ortograficznych - jest mowa na przykład o tym, że skoro Mateusz „popołudniu” (sic!) wyjeżdża z domu, to „musiało go coś przypilić” (Montgomery/Piekarski 6)). Tak słaba jakość przekładów, zwłaszcza kierowanych do młodych czytelników, musi oburzać. Dlatego nie dziwi fakt, że na tym tekście (oraz jego autorze) suchej nitki nie zostawiła Gertruda Skotnicka w dość ironicznie zatytułowanym artykule No, to sobie poprzekładamy (1997):

Bezkarnie grasują tłumacze - kiepscy rzemieślnicy - pozbawieni poczucia odpowiedzialności za całokształt artystyczny przełożonego tekstu. W błogiej nadziei, że dziecku można wcisnąć wszystko, wszak ono się na tym nie zna, ponieważ kryteria estetyczne są mu obce, powołują do życia książki, które nie spełniają podstawowych wymogów poprawności tekstu.

Absolutny rekord w ilości błędów osiągnęła Ania z Zielonego Wzgórza w przekładzie Przemysława Piekarskiego, wydana przez krakowskie wydawnictwo „Liberal”. Nie ma w niej ani jednej strony, o której z czystym sumieniem można powiedzieć, że jest bezbłędna, a suma błędów frazeologicznych, składniowych, semantycznych przekonuje, że tłumacz nie posiada dostatecznej znajomości języka polskiego (Skotnicka 1997: 97).

Badaczka przywołała co bardziej szokujące pomyłki tłumacza, pytając na koniec:

Kto za to odpowiada? Zamiast nazwiska redaktora książki na odwrocie karty tytułowej widnieje wielce enigmatyczny „Zespół”. Nie wiadomo, kto się za tym kryje, ale pewne jest, że ów „Zespół” z zasadami ortografii nigdy się nie zetknął, a interpunkcję w ogóle uważa za niepotrzebną (Skotnicka 1997: 97). 
Błędy w tłumaczeniach trzeba rzecz jasna dostrzegać i negatywnie wartościować. Niemniej jednak można się zastanawiać, czemu miała służyć tak zjadliwa krytyka oraz czy dałoby się ją nazwać konstruktywną. O wiele bardziej ogólne i wyważone, a jednocześnie zachęcające do dalszych analiz wnioski na temat tłumaczeń $\mathrm{z}$ lat dziewięćdziesiątych xx i początku xxI wieku sformułował natomiast Piotr Oczko, który stwierdził:

Niestety większość przekładów zawiera kardynalne błędy i została zrobiona niechlujnie. Porównanie tych tłumaczeń mogłoby stać się przedmiotem interesującego studium o charakterze translatologicznym. Moje pierwsze wrażenie jest następujące: najwięcej błędów i przekłamań popełnili tłumacze-mężczyźni, których przekłady ukazały się w małych wydawnictwach, jednak to oni najczęściej szukali nowatorskich (co nie znaczy, że dobrych) rozwiązań. Przekłady kobiet są znacznie staranniejsze, ale zachowawcze: rzadko kiedy widać w nich chęć poprawienia dawnych pomyłek. Być może wynika to z faktu, że za tłumaczenie Anne of Green Gables brały się wielbicielki powieści, które zbyt bardzo przywiązały się do polskiej wersji swej ukochanej książki z młodości i bały się wprowadzać do zapamiętanego przez nie tekstu Bernsteinowej zbyt dużo zmian (Oczko 47-48).

Ciekawa może się okazać próba odniesienia uwag badacza do poruszanej już nieraz przez przekładoznawców kwestii: brzmienia imienia jednej z mieszkanek Avonlea - Rachel Lynde, która w tłumaczeniu Bernsteinowej występuje jako... Małgorzata. Rzeczywiście tymi, które utrwalały zaproponowaną w kanonicznym tłumaczeniu i silnie zakorzenioną w polskiej tradycji wersję imienia bohaterki, były w większości kobiety (zob. tabela 1). Znaczący wydaje się ponadto fakt, że kilkukrotnie obecną w pierwszej wersji Rachel (bądź Rachelę) w kolejnych zastąpiono Małgorzatą, jakby tłumaczka wycofała się (trudno orzec, czy z własnej woli, czy też pod naciskiem wydawcy) z wybranego wcześniej rozwiązania (Szymańska 205). Inny ważny i często pomijany element powieści stanowi motto, będące cytatem zaczerpniętym z poematu Roberta Browninga Pippa Passes. Spośród omawianych pojawia się ono tylko w przekładach autorstwa Katarzyny Jakubiak, Jana Jackowicza oraz Przemysława Piekarskiego (poza tym można je znaleźć w polemicznych tłumaczeniach Beręsewicza i Kuc). 


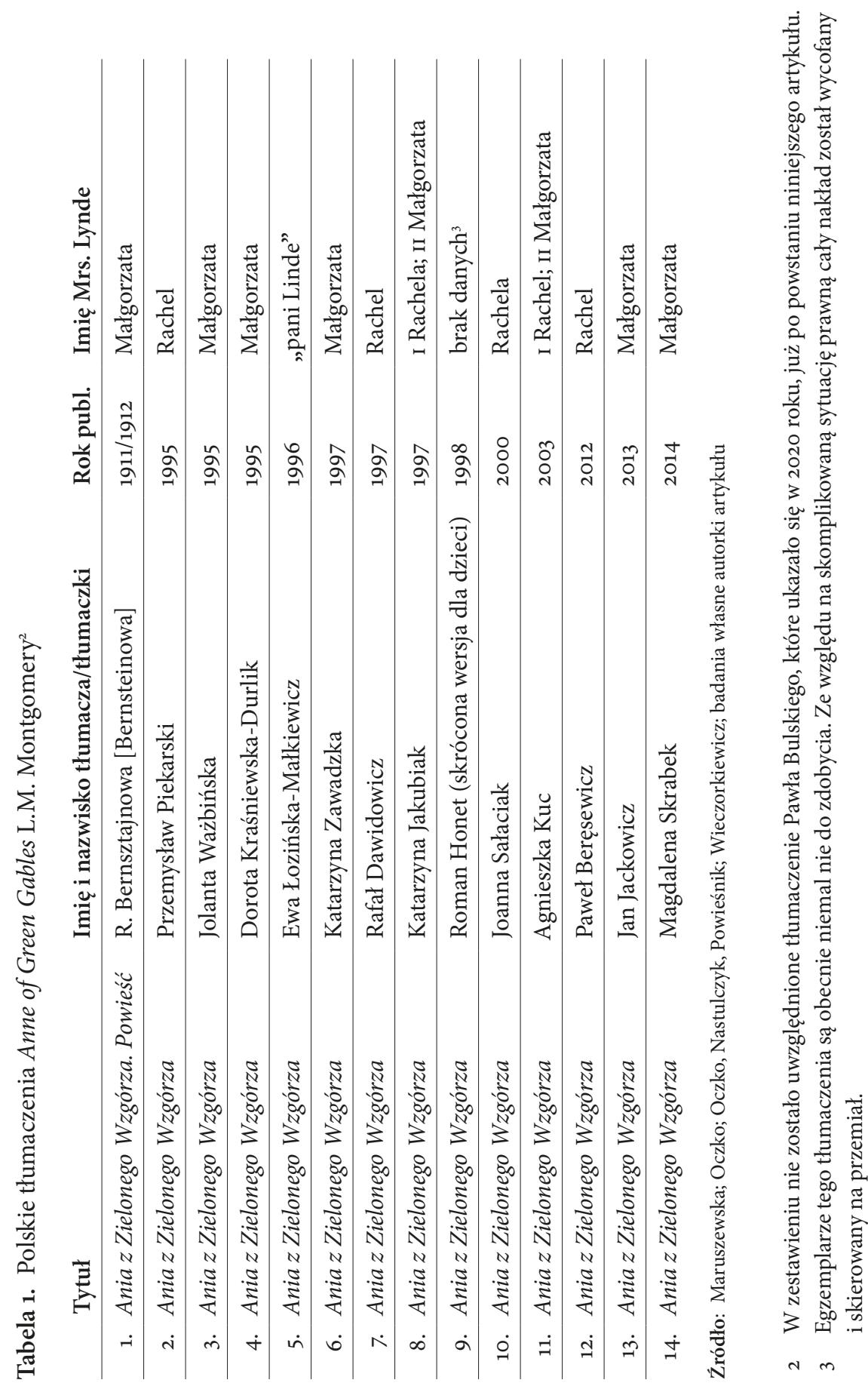


Pewne obserwacje dotyczące strategii translatorskich przyjętych przez autorów i autorki polskich przekładów Anne of Green Gables można zresztą poczynić, nawet nie otwierając tych książek. Wystarczy spojrzeć na ich okładki, by przekonać się, że żadna z tłumaczących dotychczas utwór Montgomery osób nie zdecydowała się na zmianę tytułu, który - jak wynika z badań przekładoznawczych (Oczko 46-47; Oczko, Nastulczyk, Powieśnik 275) - w polskim brzmieniu ma formę nieadekwatną do oryginalnego. Przyczyn takiej decyzji można upatrywać w braku kompetencji językowych albo kreatywności tłumaczy (chociaż nie wydaje się, by tak właśnie było) bądź wpływie wspomnianych już wcześniej względów sentymentalnych (przywiązanie do znanej i zapamiętanej z dzieciństwa nazwy, mechaniczne „przepisanie” jej bez konfrontacji z oryginałem). Jednakże za najbardziej prawdopodobny oraz najważniejszy powód pozostawienia bez zmian utrwalonego w polskiej recepcji tytułu należy uznać uwarunkowania rynkowo-marketingowe. Renoma, jaką przez dziesiątki lat cieszy się Ania z Zielonego Wzgórza (w takim właśnie brzmieniu), pozwala przypuszczać, że ta sama książka wydana pod innym tytułem mogłaby nawet nie zostać zidentyfikowana jako przekład bestselleru kanadyjskiej pisarki! ${ }^{4}$ Podobnie stawiała sprawę Skwara: „często zdarza się [...], że tłumacze celowo zachowują ten sam tytuł, bo wrósł on w tradycję kulturową, wydawniczą, wreszcie rynkową" (Skwara 2014: 22). Natomiast Izabela Szymańska, charakteryzując Anię... w tłumaczeniu Agnieszki Kuc, pisała:

Jeśli chodzi o imiona własne, tłumaczka nie próbowała zmienić tradycyjnej polskiej wersji imienia głównej bohaterki ani tytułu powieści, za co zapewne zostałaby skrytykowana podobnie jak Adamczyk-Garbowska za Fredzię; można zresztą przypuszczać, że taka próba nie zostałaby zaakceptowana przez wydawcę (Szymańska 204).

Przywołane przykłady pozwalają zwrócić uwagę na coś, co w erze badań spod znaku Translator Studies (Chesterman) wydaje się już oczywiste, jednak wówczas, gdy zaczęły się ukazywać omawiane tłumaczenia, nie było jeszcze

4 Wydaje się, że taka sytuacja ma miejsce w przypadku „prawdopodobnie najsłynniejszego polskiego przekładu polemicznego, nie tylko w literaturze dziecięcej" (Szymańska 198), czyli dokonanego przez Monikę Adamczyk-Garbowską tłumaczenia utworu Winnie-The-Pooh autorstwa Alana Alexandra Milne'a. Mniej zorientowany czytelnik nie ma dziś świadomości, że jej Fredzia Phi-Phi oraz Kubuś Puchatek (taki tytuł nosi niezwykle popularna polska wersja owej książki, stworzona przez Irenę Tuwim) to tłumaczenia tego samego tekstu. 
prawie w ogóle brane pod uwagę. Chodzi mianowicie o uwzględnianie podczas opisywania, analizowania, a zwłaszcza wartościowania przekładów wielu różnorodnych czynników oddziałujących na osobę tłumacza. Należą do nich między innymi przedsądy ${ }^{5}$ z jakimi podchodzi on/ona do tekstu, presja wydawcy, a nieraz i czytelnika, różnice między kulturą wyjściową a docelową... Warto w związku z tym pamiętać, że wrażliwość oraz wyobraźnia potrzebne są nie tylko przekładającym, ale i przekładoznawcom.

\section{3. (Nie)estetyczne okładki i marketingowe strategie}

O wiele bardziej produktywna niż skupianie się na tym, jak źle wspomniane przekłady świadczą rzekomo o samych tłumaczach, będzie zatem refleksja nad tym, co mówią o polskiej rzeczywistości przełomu xx i xxI wieku. A powiedzieć mogą wiele, choćby o sytuacji gospodarczo-ekonomicznej Polski w tamtym czasie. Wpływ kwestii marketingowych na decyzje tłumaczy został już zaakcentowany, jednak ze względu na jego wkład w zaistnienie „festiwalu kanadyjskiej pisarki” wątek ten wymaga uzupełnienia. W 1992 roku minęło 50 lat, natomiast w 2012 - 70 lat od śmierci autorki, można więc było bez obaw o naruszenie praw autorskich wydawać jej teksty. Ponadto po 1989 roku powstało w Polsce mnóstwo małych wydawnictw, chcących zapewne poprawić swoje notowania oraz ugruntować pozycję na rynku poprzez posiadanie w swej ofercie tak popularnej pozycji, jaką była (i nadal jest) Ania z Zielonego Wzgórza. Mniej skomplikowane, a przede wszystkim tańsze rozwiązanie niż zwracanie się do Naszej Księgarni o udzielenie praw do tłumaczenia Bernsteinowej stanowiło dla nich zlecenie nowych przekładów bądź nawet „przywłaszczenie” sobie istniejącego, bez zwracania uwagi na jakiekolwiek normy czy zasady etyczne. Jak zauważają badacze, chaos towarzyszący dokonującym się wówczas w Polsce zmianom ustrojowym znacząco ułatwiał takie działania:

Dawno temu „Nasza Księgarnia” zakupiła copyright na dzieła Lucy Maud i z pomocą różnych Rilli ze Złotego Brzegu i Pat ze Srebrnego

5 Rolę przedsądów w procesie poznania akcentował Hans-Georg Gadamer, który pisał następująco: „Przesądy nie muszą bynajmniej być bezzasadne i mylne w tym sensie, że przeinaczają prawdę. Z dziejowości naszej egzystencji wynika, że przesądy - przed-sądy - wyznaczają pierwotne ukierunkowanie całej naszej zdolności doświadczania. Przesądy uprzedzają i warunkują naszą otwartość na świat, dzięki przesądom możemy w ogóle czegoś doświadczać, dzięki przesądom to, z czym się stykamy, coś nam mówi” (Gadamer 313). 
Gaju wyrównywała niedobory finansowe. O ile mi wiadomo, radosna zmiana ustrojowa sprawiła, że nowi wydawcy, bez oglądania się na tytuł własności, wzięli się rześko do zalewania rynku swoimi edycjami powieści Lucy Maud; dodajmy, że zawłaszczali przy okazji i tłumaczenie, i grafikę, ograniczając się wyłącznie do zmiany stopki wydawniczej (Nowacka 1994: 56).

Warto dodać, że powieść Montgomery już od wielu lat funkcjonuje jako obowiązkowa lektura szkolna, co z pewnością również podnosi jej atrakcyjność marketingową. Jak ironicznie, ale i z pewną goryczą zauważyła w jednym ze swoich artykułów Ewa Nowacka, „pierwsze przykazanie wydawcy w Polsce brzmi obecnie: zarobić” (Nowacka 1993: 58). Chociaż słowa te pochodzą z 1993 roku, można stwierdzić, że niekoniecznie straciły aktualność.

Niestety, co częściowo wynika z omówionych wyżej działań wydawców, pod względem estetyki przekłady z przełomu xx i xxi wieku także pozostawiają wiele do życzenia. Na okładce widnieje zwykle protagonistka, jednak przedstawienie to rzadko można by nazwać adekwatnym do treści i wymowy utworu. Proponowano najróżniejsze wizje: od konwencjonalno-sielankowo-sentymentalnych obrazów Anne jako „dziewczęcia”, przez „scenki rodzajowe” nasuwające skojarzenia z baśniami (raczej w wydaniach dla młodszych czytelników) bądź pokazujące bohaterkę jako małą dziewczynkę czy wręcz lalkę, aż po przypominające stylem komiksy albo książki z serii o Mikołajku... Te tendencje mogą też świadczyć o fascynacji, a wręcz „zachłyśnięciu się” kolorowym światem Zachodu, do którego Polska w latach dziewięćdziesiątych xx wieku uzyskała dostęp. Niektóre Anie... z tamtego czasu przywodzą na myśl królujące wówczas w Europie bajki Disneya, które szybko zyskały popularność również w naszym kraju. Infantylizowane, kiczowate wizerunki rażą - szczególnie zestawione $z$ eleganckimi, estetycznymi okładkami oryginału czy pierwszego polskiego przekładu.

\section{Kanada widziana oczami Polaków}

Przyglądając się mniej znanym polskim przekładom Anne of Green Gables, należy ponadto zwrócić uwagę na obraz Kanady, który można z nich wyczytać. Magdalena Kulus w artykule zatytułowanym Wyspa Ani pokazywała, jak emocjonalnie twórczyni opisywała własną ojczyznę zarówno w pisanych właściwie przez całe życie pamiętnikach, jak i swej najbardziej znanej powieści. Pretekst do ukazania kanadyjskiej przyrody stanowiła w niej na przykład podróż bohaterki ze stacji (Kulus 5-9). 
Analizę skupiającą się bardziej na warstwie językowej przeprowadziła natomiast Marta Zborowska-Motylińska w tekście Translating Canadian Culture into Polish: Names of People and Places in Polish Translations of Lucy Maud Montgomery's "Anne of Green Gables". Co więcej, zwróciła w nim uwagę na kwestie społeczne, podkreślając, że spośród przedstawicieli wszystkich nacji oraz warstw społecznych zamieszkujących Wyspę Księcia Edwarda (gdzie rozgrywa się akcja utworu) pisarka wybrała i zobrazowała tylko jedną, dość jednolitą etnicznie grupę - prostych farmerów. W powieści nie pojawiają się na przykład rdzenni mieszkańcy Kanady, zaś osoby o pochodzeniu francuskim pełnią role marginalne ${ }^{6}$. Wydaje się to znaczące o tyle, że dla Polaków Montgomery jest pierwszą - a nierzadko jedyną - pisarką kojarzoną z tym krajem, zaś samą Kanadę nasi rodacy znają czasem wyłącznie z jej książek (a dokładniej - z ich polskich przekładów). Wszystko to oczywiście przyczynia się do ukształtowania obrazu uproszczonego, niepełnego, opartego na stereotypach. Na przykład poetyckie w mniemaniu czytelników Ani... nazwy miejscowe nie są w Kanadzie niczym niezwykłym, a w oryginale - na co zwraca uwagę Oczko - brzmią neutralnie:

„Literackie” angielskie nazwy miejscowe w Ameryce Północnej, zarówno w Kanadzie, jak i Stanach Zjednoczonych, powstawały w innych warunkach kulturowych i dla tamtejszych odbiorców są one neutralne (Death Valley, Cold Lake, Spruce Grove) uległy bowiem leksykalizacji. Podawanie polskich odpowiedników współgra co prawda z pojawiającymi się w powieściach sentymentalnymi nazwami (Anna Shirley określa np. staw Barrych „Jeziorem Lśniących Wód” i tu przekład jest niezbędny), ale niepotrzebnie zwiększa wrażenie egzaltacji. Anglojęzyczny czytelnik widzi różnicę między Maywater i Lake of Shining Waters, w polszczyźnie Majowe Wody i Jezioro Lśniących Wód brzmią równie literacko (i pretensjonalnie) (Oczko 48).

6 Jedną z takich osób jest parobek Cuthbertów - Jerry Buote. O bardzo niskim statusie chłopca może świadczyć szokująca dla współczesnego odbiorcy wypowiedź Marilli: „No dobrze, idź teraz i zanieś to ciasto świniom - powiedziała Maryla. - Dla ludzi się nie nadaje. Nawet dla Jerry'ego Buote’a” (Montgomery/Beręsewicz 212). Nota bene w niektórych tłumaczeniach, począwszy od kanonicznego, fragment odnoszący się do Jerry’ego został złagodzony bądź usunięty: „Tak, tak, ale teraz zanieś to ciasto wieprzkom - rzekła Maryla. - Żaden człowiek nie potrafiłby tego przełknąć” (Montgomery/ Bernsteinowa 176); „Dobrze, już dobrze. Idź no lepiej i rzuć ten tort świniom - rzekła Maryla. - Nie nadaje się do jedzenia dla nikogo, nie można nawet dać go parobkowi” (Montgomery/Łozińska-Małkiewicz 172). 
Natomiast element kulturowy, który - mimo iż występuje także w Polsce może wywoływać nieporozumienia i utrudniać polskiemu odbiorcy lekturę oryginału, to kwestia używania imienia męża zamiast jej własnego, kiedy mówi się o zamężnej kobiecie. I tak na przykład żona Alexandra Spencera określana jest na kartach powieści „Mrs. Alexander Spencer”. Nie wszyscy tłumacze zrozumieli w tym miejscu znaczenie oryginału, a przynajmniej nie wszyscy zdecydowali się użyć polskiego odpowiednika tej konstrukcji. W przekładzie Katarzyny Jakubiak widnieje na przykład odpowiadająca formie występującej w oryginale „pani Aleksandrowa Spencer”, natomiast Przemysław Piekarski nazywa tę postać „pani Spencer” bądź... „pani Aleksandra Spencer”. Od tej zasady są jednak w powieści wyjątki. Mrs. Rachel Lynde - niezwykle energiczna kobieta i dominująca nad mężem żona - zawsze nazywana jest swoim własnym imieniem, z kolei o jej mężu Thomasie mówi się zwykle „Rachel’s Lynde husband” [„mąż Rachel Lynde”]. W zależności od wyboru strategii translatorskiej ta znacząca opozycja zostaje zatem podkreślona lub przeciwnie - zanika (zob. Zborowska-Motylińska 158).

Oprócz tytułowych zielonych dachów („green gables”) w powieści pojawiają się dodatkowo inne charakterystyczne dla tego regionu Kanady elementy, między innymi czerwone drogi. Kiedy Anne po raz pierwszy przyjeżdża na Wyspę Księcia Edwarda, na ich widok bardzo się dziwi. Analiza sposobu, w jaki jej wypowiedź ukształtowana została przez Montgomery, a później oddana w polskich tłumaczeniach, pozwala wskazać na kilka interesujących cech i ważnych różnic między omawianymi tłumaczeniami. Jako punkt wyjścia potraktować należy cytat z oryginału, jak również przekład Bernsteinowej’:

It's delightful when your imaginations come true, isn't it? But those red roads are so funny (Montgomery 18).

A czyż to nie rozkoszne, jeśli sen się spełnia?... Jakże te czerwone drogi są dziwne! (Montgomery/Bernsteinowa 20).

7 Podaję to zdanie $\mathrm{w}$ takim brzmieniu, $\mathrm{w}$ jakim znaleźć je można $\mathrm{w}$ cytowanym już wcześniej wydaniu Ani... z 1990 roku, bo jeśli tłumacze posiłkowali się przekładem kanonicznym albo pamiętali go $\mathrm{z}$ dzieciństwa, prawdopodobnie nie było to żadne z pierwszych, obecnie trudno dostępnych wydań (na przykład z 1912 czy 1921 roku), a jedno z niezwykle rozpowszechnionych powojennych, które - chociaż nadal sygnowane nazwiskiem Bernsteinowej - po ingerencji redaktorów znacznie różniły się od tych $\mathrm{z}$ początku xx wieku. Wszystkie zaznaczenia w cytowanych fragmentach powieści pochodzą od autorki artykułu. 
Już w tym jednym zdaniu zauważyć można typową dla polskiego przekładu kanonicznego sentymentalizację, posługiwanie się wyszukanym, pełnym patosu słownictwem („a czyż to nie rozkoszne”), które dla współczesnego czytelnika - zwłaszcza młodego - brzmi obco, sztucznie, a nawet komicznie. Także konstrukcja „sen się spełnia” nie należy już dziś do bardzo popularnych. Z kolei zastąpienie przez Bernsteinową angielskiego funny wyrazem „dziwny” to decyzja nieco zaskakująca, choć gramatycznie poprawna ${ }^{8}$. Autorzy i autorki analizowanych przekładów z przełomu xx i xxı wieku próbowali - bardziej lub mniej udanie - zastosować wyrażenia częściej występujące we współczesnej polszczyźnie. Jednocześnie wydaje się, że i w tym wypadku na niektóre decyzje wpływ miał przekład kanoniczny:

To cudowne, gdy nasze marzenia się sprawdzają, czyż nie? Ale te czerwone drogi są zabawne (Montgomery/Dawidowicz 12).

To cudowne, kiedy marzenia stają się prawdą, czyż nie? Ale te czerwone drogi są zabawne (Montgomery/Piekarski 14).

To takie piękne, kiedy marzenia się spełniają, prawda? Ale dziwne te czerwone drogi! (Montgomery/Sałaciak 15).

To zachwycające, gdy marzenia się spełniają, prawda? Jakie śmieszne są te czerwone drogi! (Montgomery/Łozińska-Małkiewicz 18).

...nie sądziłam, że moje marzenia się spełnią. Te czerwone drogi są takie zabawne (Montgomery/Ważbińska 17).

To cudowne, gdy marzenia się spełniają, prawda? A te czerwone drogi są takie zabawne (Montgomery/Jakubiak 16).

Jak to miło, kiedy marzenia zamieniają się w rzeczywistość, prawda? Ale te czerwone drogi są trochę śmieszne (Montgomery/Jackowicz 18).

Jakie to cudowne, kiedy marzenia się spełniają, prawda? Przedziwne są te czerwone drogi tutaj (Montgomery/Zawadzka 18).

8 Jako drugie znaczenie słowa funny internetowy słownik Oxford Advanced Learner's Dictionary podaje: strange, difficult to explain or understand, czyli właśnie 'dziwny, trudny do wytłumaczenia lub zrozumienia'. (Oxford Advanced Learner's Dictionary, źródło elektroniczne). 
Jakie to cudowne, kiedy spełniają się marzenia. A te czerwone drogi są takie zabawne (Montgomery/Kraśniewska-Durlik 16).

Na podstawie zaprezentowanego przykładu można stwierdzić, że intuicje badawcze Oczki w większości przypadków się sprawdziły. Tłumaczki najczęściej stosowały (tak jak Bernsteinowa) najprostszą i najpopularniejszą formę: „marzenia się spełniają” (ewentualnie z drobnymi przekształceniami). Natomiast tłumacze-mężczyźni próbowali modyfikować utrwalony w polszczyźnie w takiej właśnie wersji zwrot, czego efektem były czasami nie najlepiej brzmiące konstrukcje (np. „marzenia zamieniają się w rzeczywistość”, „marzenia się sprawdzają”). Niezwykle interesujący jest przy tym fakt, że bez względu na płeć, wszyscy przekładający Anne of Green Gables na przełomie xx i xxi wieku zdecydowali się przetłumaczyć angielskie imaginations jako „marzenia”. Oczywiście pasuje to do kontekstu jako element utartego zwrotu „marzenia się spełniają”. Równocześnie jednak użycie tego wyrazu sprawia, że ginie zauważalne w oryginale odniesienie do niezwykle istotnej w konstrukcji psychicznej oraz tożsamości bohaterki jej skłonności do fantazjowania (Pielorz). Za bardziej trafne i adekwatne można by zatem uznać umieszczenie w tym zdaniu na przykład słowa „wyobrażenia”. Konfrontacja z oryginałem i wzięcie pod uwagę kontekstu rzuca też nowe światło na przekład kanoniczny, nasuwając skojarzenie ze „snami na jawie”. Z kolei występujący w oryginale przymiotnik funny najczęściej tłumaczony jest przez współczesnych tłumaczy najprościej, jako „śmieszne” bądź „zabawne”. Najdalej od tej wersji odchodzą tłumaczki: Joanna Sałaciak i Katarzyna Zawadzka, ale one z kolei wybierają, być może na zasadzie prostego powielenia, różne warianty tego samego określenia, które pojawiło się w kanonicznym przekładzie Bernsteinowej (odpowiednio: „dziwne”, „przedziwne”).

Warto również pokazać, jakie tłumaczenia wypowiedzi Anne zaproponowali autorzy przekładów polemicznych:

To cudowne, gdy nasze marzenia się spełniają, prawda? Ależ dziwne są te rudoczerwone drogi (Montgomery/Kuc 24).

To cudowne, kiedy marzenia się spełniają, prawda? Strasznie śmieszne są te czerwone drogi (Montgomery/Beręsewicz 23).

Ich autorzy pozostają przy formie „marzenia się spełniają”. Warto zaznaczyć, że Kuc jako jedyna „zmienia” kolor dróg z czerwonego na rudoczerwony, natomiast Beręsewicz dodaje do ich opisu może nie do końca poprawne, ale często używane w języku potocznym określenie „strasznie” („strasznie śmieszne”). 
Na podstawie lektury polskiego przekładu czytelnik może postrzegać Kanadę jako spokojne, dostatnie miejsce, gdzie na wsi ludzie żyją w... „dworkach” tak bowiem przełożyła występujące w oryginale słowo farms Bernsteinowa. Trzeba jednak pamiętać, na co wskazywał we wspomnianym już kilkukrotnie artykule Oczko, że choć akcja utworu rzeczywiście rozgrywa się na prowincji w drugiej połowie XIX wieku, w domu trudniących się rolnictwem Cuthbertów znaleźć można takie przedmioty jak srebrna zastawa, stara porcelana czy ametystowa broszka. Między wsią polską a kanadyjską istniała bowiem wówczas „przepaść cywilizacyjna”. Być może użycie przez Bernsteinową wyrazu „dworki” na określenie domostw mieszkańców Avonlea służyć miało uwypukleniu tej różnicy (Oczko 48). Za dobry pomysł należy uznać zamienienie tego słowa w kolejnych przekładach na bardziej współczesne „gospodarstwo” (np. Jakubiak, Sałaciak, Dawidowicz), „dom” czy „domek”. Najbardziej oryginalny okazał się w tym wypadku Jan Jackowicz, wybierając wyraz „zagroda”. Wydaje się jednak, że to jeden z przypadków, kiedy zaproponowane przez tłumacza rozwiązanie, choć innowacyjne, niekoniecznie okazuje się adekwatne. Wracając do przekładu kanonicznego, można stwierdzić, że dla młodych czytelników xxı wieku słowo „dworek” byłoby nawet mniej zrozumiałe niż oryginalne farms bądź polskie „farma”. To ciekawy przypadek sytuacji, w której - nieco paradoksalnie - zastosowanie udomowienia czyni przekład bardziej egzotycznym, zaś egzotyzacja przybliża tekst czytelnikowi. To zjawisko można uznać za skutek globalizacji, szybszego przepływu informacji, a jednocześnie coraz mniejszej świadomości dotyczącej przeszłości. W efekcie obecnie rzeczywistość współczesna, mimo iż oddalona o tysiące kilometrów, jest odbiorcy (zwłaszcza młodemu) bliższa niż „własne podwórko”, ale w kształcie z ubiegłego wieku (wszak od powstania kanonicznego przekładu Ani... minęło już niemal 110 lat).

Interesujące byłoby spojrzenie na ów „polski renesans całej [...] twórczości” (Skotnicka 1996: 16) Montgomery jako na zjawisko, które oprócz kontekstów marketingowych, estetycznych, kulturowych czy społecznych da się rozpatrywać także w odniesieniu do problemów dydaktyki, pedagogiki, a nawet psychologii. Można bowiem zauważyć konkretne modele, wzorce postępowania pokazywane i afirmowane przez autorkę. Na ich wybór oraz zilustrowanie mają oczywiście wpływ realia, w których żyła oraz tworzyła Kanadyjka9. Podążając tym tropem, warto byłoby też prześledzić, czy i ewentualnie w jaki sposób stylistyczno-językowy kształt tłumaczeń oddziałuje na ich wymowę. Szczególnie doniosłe

9 Warto jednak zwrócić uwagę na nowatorstwo oraz postępowe poglądy kanadyjskiej pisarki. Ich wyraz znaleźć można zarówno w dziennikach, jak i w twórczości Montgomery, o czym wspominam w innym miejscu (Pielorz 37-44). 
konsekwencje może mieć w tym wypadku dominujący - jak się wydaje - wybór strategii udomowienia. Z jednej strony z pewnością pozytywnie wpłynął on na odbiór powieści przez polskich czytelników (czytelniczki), ułatwiając im identyfikację z protagonistką. Z drugiej natomiast przyczynił się do ukształtowania i zakorzenienia w polskiej kulturze oraz masowej świadomości obrazu Anne jako niemal „polskiego dziewczęcia” (Oczko 45). Tego tematu, jako wykraczającego poza obręb niniejszego artykułu, nie będę jednak rozwijać.

\section{Podsumowanie}

Bez względu na to, czy mówi się o serii translatorskiej, czy - w szerszym ujęciu - serii recepcyjnej Ani z Zielonego Wzgórza, ma ona z natury charakter otwarty (Balcerzan 18). Stanowi przy tym ciekawy materiał do dalszych badań i analiz przekładoznawczych, literaturoznawczych, a także kulturoznawczych oraz socjologicznych. Namysł tego rodzaju wydaje się bardziej potrzebny i owocny niż ograniczenie się do krytykowania czy wręcz ośmieszania poszczególnych tłumaczeń, nawet jeśli same teksty zdają się dostarczać ku temu powodów. W polskich przekładach najpopularniejszej powieści Montgomery można bowiem dostrzec elementy obrazu Kanady widzianej oczami Polaków, ale w pewnym sensie również obraz ich samych oraz rodzimej rzeczywistości w jej kształcie z przełomu xx i xxi wieku. Od tamtego czasu w literaturze dla dzieci i młodzieży wiele się zmieniło. Na szczęście publikowanych jest mniej niedbale wydanych, usianych błędami czy „ozdobionych” kiczowatymi, brzydkimi obrazkami książek, a przedstawiciele najmłodszej generacji „polskiej szkoły ilustracji” zdobywają nagrody w międzynarodowych konkursach. Niestety, takim przemianom niekoniecznie uległa mentalność - wciąż można spotkać się z niewiedzą i wynikającym z niej uproszczonym, stereotypowym postrzeganiem innych nacji, grup społecznych czy etnicznych. Uważam, że stojące na wysokim poziomie rodzime oraz dobrze przetłumaczone obcojęzyczne książki dla młodych odbiorców przyczyniają się do zmiany tej niekorzystnej sytuacji. Wracając natomiast do recepcji twórczości Montgomery, bez obaw o nadużycie można stwierdzić, że ogłoszony niemal 30 lat temu „festiwal kanadyjskiej pisarki” trwa w naszym kraju do dziś. 


\section{| Bibliografia}

Twórczość Lucy Maud Montgomery ORAZ POLSKIE PRZEKŁady

Montgomery, Lucy Maud. Anne of Green Gables. New York-London: W.W. Norton \& Company, 2007.

Montgomery, Lucy Maud. Ania z Zielonego Wzgórza. Przeł. Rozalia Bernsteinowa. Warszawa: Nasza Księgarnia, 1990.

Montgomery, Lucy Maud. Ania z Zielonego Wzgórza. Przeł. Dorota Kraśniewska-Durlik. Wrocław: Siedmioróg, 1995.

Montgomery, Lucy Maud. Ania z Zielonego Wzgórza. Przeł. Przemysław Piekarski. Kraków: Liberal, 1995.

Montgomery, Lucy Maud. Ania z Zielonego Wzgórza. Przeł. Ewa Łozińska-Małkiewicz. Toruń: Algo, 1996.

Montgomery, Lucy Maud. Ania z Zielonego Wzgórza. Przeł. Katarzyna Jakubiak. Kraków: Zielona Sowa, 1997.

Montgomery, Lucy Maud. Ania z Zielonego Wzgórza. Przeł. Katarzyna Zawadzka. Warszawa: Kama, 1997.

Montgomery, Lucy Maud. Ania z Zielonego Wzgórza. Przeł. Rafał Dawidowicz. Bielsko-Biała: Klasyka, 1997.

Montgomery, Lucy Maud. Ania z Zielonego Wzgórza. Przeł. Jolanta Ważbińska. Kraków: Warszawa: Hubert, 2002.

Montgomery, Lucy Maud. Ania z Zielonego Wzgórza. Przeł. Agnieszka Kuc. Kraków: Wydawnictwo Literackie, 2007.

Montgomery, Lucy Maud. Ania z Zielonego Wzgórza. Przeł. Jan Jackowicz. Wrocław: Siedmioróg, 2013.

Montgomery, Lucy Maud. Ania z Zielonego Wzgórza. Przeł. Joanna Sałaciak. Poznań: G\&P, 2013.

Montgomery, Lucy Maud. Ania z Zielonego Wzgórza. Przeł. Paweł Beręsewicz. Kraków: Skrzat, 2013.

Montgomery, Lucy Maud. Ania z Zielonego Wzgórza. Przeł. Magdalena Skrabek. Kraków: Greg, 2017.

\section{LITERATURA PRZEDMIOTU}

Balcerzan, Edward. Literatura z literatury (strategie tłumaczy). Katowice: Śląsk, 1998.

Chesterman, Andrew. „The Name and Nature of Translator Studies”. Hermes - Journal of Language and Communication Studies 42 (2009). S. 13-22. Web. 1.10.2019. <https://tinyurl.com/y8ulcwst>

Gadamer, Hans-Georg. „Uniwersalność problemu hermeneutycznego”. Przeł. Małgorzata Łukasiewicz. Pamiętnik Literacki 4 (1977). S. 309-319. 
Horodecka, Anna. „Ta sławna Lucy Maud”. Guliwer 5 (1994). S. 18-21.

Horodecka, Anna. „Jak miłe są wspomnienia!”. Guliwer 5 (1995). S. 29-30.

Kulus, Magdalena. „Wyspa Ani”. Guliwer 2 (2008). S. 5-9.

Legeżyńska, Anna. Tłumacz i jego kompetencje autorskie. Warszawa: PwN, 1999.

Maruszewska, Agnieszka. Pokrewne dusze Maud. Świat

Lucy Maud Montgomery w Polsce. 2017. Web. 29.09.2019.

$<$ http://pokrewne-dusze-maud.blogspot.com/>

Nowacka, Ewa. „Trzy premiery przekładowe”. Nowe Książki 5 (1993). S. 57-58.

Nowacka, Ewa. „Kaszka manna - smaczna czy mdła?”. Nowe Książki 4 (1994).

S. 56-58.

Oczko, Piotr. „Anna z domu o zielonym dachu. O cyklu powieściowym Lucy Maud Montgomery". Teksty Drugie 5 (2013). S. 42-61.

Oczko Piotr, Nastulczyk Tomasz, Powieśnik Dorota. „Na szwedzkim tropie Ani z Zielonego Wzgórza. O przekładzie Rozalii Bernsteinowej”. Ruch Literacki 3 (2018). S. 261-280.

Oxford Advancced Learner's Dictionary. 2019. Web. 1.10.2019. < https://tinyurl. com/yd5ofnpn>

Pielorz, Dorota. „Od przyszłości / ku przyszłości - fantazmaty tytułowej bohaterki powieści „Ania z Zielonego Wzgórza” Lucy Maud Montgomery”. Literatura Ludowa 63(2) (2019). S. 32-44.

Skotnicka, Gertruda. „Kopciuszek w kolorowych okładkach”. Guliwer 4 (1994). S. 22-24.

Skotnicka, Gertruda. „Krewniaczki Ani”. Nowe Książki 6 (1996). S. 16-17.

Skotnicka, Gertruda. „No, to sobie poprzekładamy”. Nowe Książki 3 (1997). S. 79.

Skwara, Marta. „Polski Whitman”. O funkcjonowaniu poety obcego w kulturze narodowej. Kraków: Universitas, 2010.

Skwara, Marta. Polskie serie recepcyjne wierszy Walta Whitmana. Monografia wraz $z$ antologia przekładów. Kraków: Universitas, 2014.

Szymańska, Izabela. „Przekłady polemiczne w literaturze dziecięcej”. Rocznik Przekładoznawczy. Studia nad teoria, praktyka i dydaktyka przekładu 9 (2014). S. 193-208. Web. 29.09.2019. <https://tinyurl.com/y8lys6vy>

Tylicka, Barbara. „Festiwal kanadyjskiej pisarki”. Guliwer 1 (1992). S. 24-25.

Tylicka, Barbara. „Sto lat temu w Kanadzie”. Nowe Książki 11 (2000). S. 73.

Wieczorkiewicz, Aleksandra. „ «Złoty wiek»: oddalenia, przekroje. 8o lat anglosaskiej klasyki dla dzieci i 150 lat jej przekładów na język polski w trzech makroperspektywach". Forum Poetyki 8 (2017). S. 66-91. Web. 4.03.2018. $<$ https://tinyurl.com/yaeamas2>

Zarek, Józef. „Przekład jako aktualizacja”. Przekład artystyczny. T. 1. Problemy teorii i krytyki. Red. P. Fast. Katowice: Uniwersytet Śląski, 1991. S. 50-51.

Zarzycka, Justyna. „Igraszki z tłumaczeniami”. Dekada Literacka 13 (1993). S. 9. 
Zborowska-Motylińska, Marta. “Translating Canadian Culture into Polish: Names of People and Places in Polish Translations of Lucy Maud Montgomery's «Anne of Green Gables»". Acta Universitatis Lodziensis. Folia Litteraria Anglica 7 (2007). S. 153-161.

\section{| Abstrakt}

\section{Dorota Pielorz}

„Festiwal kanadyjskiej pisarki”, czyli o mniej znanych polskich tłumaczeniach Anne of Green Gables Lucy Maud Montgomery

Artykuł poświęcony jest polskim tłumaczeniom powieści Anne of Green Gables L.M. Montgomery. Autorka skupia się przede wszystkim na tych przekładach, które pochodzą z lat dziewięćdziesiątych xx oraz pierwszych dekad xxI wieku. Zapoczątkowany wówczas renesans popularności twórczości Montgomery, określany mianem „festiwalu kanadyjskiej pisarki”, to fenomen jednocześnie kulturowy i wydawniczo-marketingowy, wpływający na gusta czytelników, ale również na decyzje wydawców oraz tłumaczy. W artykule omówione zostały niektóre aspekty tego zjawiska. Natomiast zarys analizy wybranych fragmentów przekładów przeprowadzono w taki sposób, by pokazać wpisany w nie przez tłumaczy oraz tłumaczki obraz Kanady. Jednocześnie autorka zwraca uwagę na fakt, że polskie Anie... mogą stanowić źródło wiedzy o różnych aspektach rzeczywistości naszego kraju na przełomie xx i xxI wieku, zwłaszcza o polityce wydawniczej oraz panujących w rodzimej kulturze normach czy modach estetycznych, a także pokutujących stereotypach.

Słowa kluczowe: Ania z Zielonego Wzgórza, Lucy Maud Montgomery, literatura kanadyjska, studia przekładoznawcze, recepcja, literatura dla dzieci i młodzieży

\section{| Abstract}

Dorota Pielorz

'A festival of the Canadian Writer' or on the Lesser Known Polish Translations of Anne of Green Gables by Lucy Maud Montgomery

The article deals with Polish translations of Lucy Maud Montgomery's book Anne of Green Gables. The author focuses especially on the renderings published at the 
turn of the $21^{\text {st }}$ century, when the so called "festival of the Canadian writer" began. This phrase is used in reference to the renascence of the popularity of Montgomery's work in Poland. This cultural and marketing phenomenon not only affected readers, but also influenced the publishers' and translators' choices. In the article, some dimensions of this casus are discussed. Then some excerpts of translations are compared in order to show the features of the image of Canada inscribed in them by translators. What is more, the author points out that the Polish renderings can provide interesting information about the different aspects of Polish reality at the turn of the $21^{\text {st }}$ century, in particular about the publishing policies and the Polish culture, aesthetic norms and trends or stereotypes.

Keywords: Anne of Green Gables, Lucy Maud Montgomery, Canadian literature, translation studies, reception, children and young adult literature

\section{| Nota o autorze}

Dorota Pielorz - doktorantka na Wydziale Polonistyki Uniwersytetu Jagiellońskiego, absolwentka polonistyki-komparatystyki na tej samej uczelni. Interesuje się szeroko pojętą literaturą dziecięcą oraz młodzieżową zarówno polską, jak i zagraniczną. Dotychczas zajmowała się badaniem początków polskiej recepcji twórczości Lucy Maud Montgomery oraz tłumaczeń najpopularniejszego utworu tej autorki, natomiast obecnie analizuje socjologiczny wymiar polskiej literatury młodzieżowej okresu PRL-u. Do obszaru jej zainteresowań naukowych należy ponadto problematyka przekładu, zwłaszcza zagadnienia związane z tłumaczeniem tekstów kierowanych do młodego odbiorcy. Brała udział w polskich i międzynarodowych konferencjach literaturoznawczych, a także przekładoznawczych. Jest autorką artykułów związanych z tymi dziedzinami.

E-mail: powiesnik.dorota@gmail.com 
